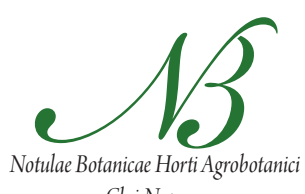

Cluj-Napoca

\title{
Evaluation of Six Methods for Extraction of Total RNA from Loquat
}

\author{
Zhang LING, Zhang ZHIKE*, Lin SHUNQUAN, Zheng TINGTING, Yang XIANGHUI** \\ College of Horticulture, South China Agricultural University, Guangzhou 510642, China; \\ gzyxh@scau.edu.cn ( ${ }^{*}$ co-first authors, ${ }^{* *}$ corresponding author)
}

\begin{abstract}
Trizol extraction for polysaccharide-rich plant tissue was unsuitable for isolating total RNA from loquat fruit. CTAB-LiCl extraction was improved with pretreatment using washing buffer with $80 \%$ ethanol and $70 \%$ acetone. The RNA isolated by this protocol from different loquat fruit tissue at various development periods, was high in purity $\left(\mathrm{A}_{260} / \mathrm{A}_{280}\right.$ ratio ranged from 1.81 to 1.99 and $\mathrm{A}_{260} / \mathrm{A}_{230}$ ratio was over 2.0), and high in yield.
\end{abstract}

Keywords: Eriobotrya japonica, RNA extraction

\section{Introduction}

Loquat (Eriobotrya japonica Lindl, Rosaceae, subfamily Maloideae), is indigenous to China, but is now cultivated worldwide in suitable climates. Loquat contains high level of polysaccharides, proteins, and secondary metabolites such as polyphenols (Liu et al., 2005) that cause degradation and low yield of functional mRNA (Wang et al., 2000). In this study, six methods for total RNA extraction of loquat fruit were compared and evaluated.

\section{Materials and methods}

\section{Materials}

Fruit of loquat (Eriobotrya japonica Lindl. cv. 'Zaozhong' No.6) were selected at different maturities from the germplasm collection of the College of Horticulture in South China Agricultural University, Guangzhou. The samples, including loquat peel and pulp, were frozen immediately by liquid nitrogen and stored at $-70^{\circ} \mathrm{C}$. Plastic ware were immersed in $0.1 \%(\mathrm{v} / \mathrm{v})$ diethyl pyrocarbonate (DEPC) treated water at $37^{\circ} \mathrm{C}$ overnight and then autoclaved $1 \mathrm{~h}$ at $12^{\circ} \mathrm{C}$. Glassware and the mortar were baked for $6 \mathrm{~h}$ at $20^{\circ} \mathrm{C}$. The samples were ground into fine power in liquid nitrogen with a pre-cooled mortar.

\section{Total RNA extraction}

\section{Method 1}

The protocol developed was based on the previously improved trizol extraction of Lin and Chen (2008). Frozen sample powder $(0.2 \mathrm{~g})$ was transferred to a $2 \mathrm{ml}$ centrifuge tube with $1 \mathrm{ml}$ RNA iso-mate for Plant Tissue (TaKaRa, Japan), mixed well, and then stored at room temperature for $5 \mathrm{~min}$. Supernatant was collected after centrifuging at $12,000 \mathrm{~g}$ for $5 \mathrm{~min}$ at $4^{\circ} \mathrm{C}$ to which an equal volume of
Trizol and $1 / 10$ volume of anhydrous ethanol was added, mixed well, and then centrifuged for $10 \mathrm{~min}$ at $12,000 \mathrm{~g}$ at $4^{\circ} \mathrm{C}$. RNA crude product was extracted with $0.2 \mathrm{ml}$ chloroform, vigorously vortexed and centrifuged at $12,000 \mathrm{~g}$ for $5 \mathrm{~min}$ at $4^{\circ} \mathrm{C}$ after incubated at room temperature for $5 \mathrm{~min}$. The supernatant was transferred to a new tube and add an equal volume anhydrous ethanol was added. mixed well and centrifuged at $1,500 \mathrm{~g}$ for $10 \mathrm{~min}$ at $4^{\circ} \mathrm{C}$ after remaining at room temperature for $10 \mathrm{~min}$. The supernatant was discarded and $200 \mu \mathrm{l} 4 \mathrm{M} \mathrm{LiCl}$ added to suspended precipitate, placed in $-20^{\circ} \mathrm{C}$ for $1 \mathrm{~h}$. After centrifugation at $12,000 \mathrm{~g}$ for $20 \mathrm{~min}$ at $4^{\circ} \mathrm{C}$, the RNA pellet was washed twice with $75 \%(\mathrm{v} / \mathrm{v})$ alcohol, air-dried, then dissolved in $20 \mu \mathrm{l}$ RNase-free water and stored at $-70^{\circ} \mathrm{C}$.

\section{Method 2}

RNAiso for polysaccharide-rich plant tissue (TaKaRa, Japan) was used as RNA extraction buffer. The procedure was performed according to the manufacturer's direction except that the RNA extraction buffer contained 2\% (w/v) $\beta$-mercaptoethanol. The RNA pellet was dissolved in $20 \mu \mathrm{l}$ RNase-free water and stored at $-70^{\circ} \mathrm{C}$.

\section{Method 3}

The protocol was modified based on the CTAB-LiCl extraction method of Song et al. (2011). Frozen sample powder $(0.2 \mathrm{~g})$ was transferred to a $2 \mathrm{ml}$ centrifuge tube containing $1 \mathrm{mlCTAB}$ extraction buffer [ $3 \%(\mathrm{w} / \mathrm{v}) \mathrm{CTAB}$, $100 \mathrm{mM}$ Tris- $\mathrm{HCl}(\mathrm{pH} 8.0), 1.4 \mathrm{M} \mathrm{NaCl}, 20 \mathrm{~mm}$ EDTA ( $\mathrm{pH}$ 8.0), 2\% (w/v) PVPP, 2\% (w/v) $\beta$-mercaptoethanol and $80 \mu \mathrm{g} \cdot \mathrm{ml}^{-1}$ proteinase $\left.\mathrm{K}\right]$ mixed well and incubated at $65^{\circ} \mathrm{C}$ for $30 \mathrm{~min}$ with occasional shaking. The supernatant was collected by centrifuging at $8,000 \mathrm{~g}$ for $15 \mathrm{~min}$ at room temperature and an equal volume of chloroform-isoamyl alcohol $(24: 1, \mathrm{v} / \mathrm{v})$ was added, mixed well and centrifuged at $12,000 \mathrm{~g}$ for $15 \mathrm{~min}$ at $4^{\circ} \mathrm{C}$. The supernatant was collect- 
314

ed again and $1 / 3$ volume of $10 \mathrm{M} \mathrm{LiCl}$ was added, mixed well and incubated on ice overnight. After centrifugation at $12,000 \mathrm{~g}$ for $30 \mathrm{~min}$ at $4^{\circ} \mathrm{C}$, the RNA precipitate was washed twice with $200 \mu \mathrm{l} 4 \mathrm{M} \mathrm{LiCl}$. The precipitate was collected by centrifugation at $12,000 \mathrm{~g}$ for $30 \mathrm{~min}$ at $4^{\circ} \mathrm{C}$ and suspended with $200 \mu \mathrm{l}$ of $10 \mathrm{mM}$ Tris- $\mathrm{HCl}(\mathrm{pH} 7.5)$, to which was added $1 / 10$ volume of $3 \mathrm{~mol} \cdot \mathrm{L}^{-1}$ potassium acetate ( $\mathrm{pH}$ 5.5) and kept on ice for $30 \mathrm{~min}$, then separated by centrifuging at $12,000 \mathrm{~g}$ for $15 \mathrm{~min}$ at $4^{\circ} \mathrm{C}$. The collected supernatant with the addition of 2.5 volume of cold anhydrous ethanol was stored for 2 to $3 \mathrm{~h}$ at $-70^{\circ} \mathrm{C}$. After centrifugation for $20 \mathrm{~min}$ at $12,000 \mathrm{~g}$ and $4^{\circ} \mathrm{C}$, the RNA pellet was collected, washed twice with $75 \%(\mathrm{v} / \mathrm{v})$ ethanol, air-dried, then dissolved in $20 \mu \mathrm{l}$ RNase-free water and stored at $-70^{\circ} \mathrm{C}$.

\section{Method 4}

Frozen sample powder $(0.2 \mathrm{~g})$ was transferred into a 2 $\mathrm{ml}$ centrifuge tube, and $1 \mathrm{ml}$ washing buffer $[100 \mathrm{mMTris}$ $\mathrm{HCl}\left(\mathrm{pH}\right.$ 8.0), $0.35 \mathrm{M}$ Sorbitol, $5 \mathrm{mM}$ EDTA, $100 \mathrm{~g} \cdot \mathrm{L}^{-1}$ PEG6000] was added, mixed well and centrifuged at 8,000 $g$ for $10 \mathrm{~min}$ at room temperature. The supernatant was discarded and, $1 \mathrm{ml} 3 \%$ CTAB extraction buffer was added. The additional steps follow Method 3 as described.

\section{Method 5}

Frozen sample powder $(0.2 \mathrm{~g})$ were transferred to a 2 $\mathrm{ml}$ centrifuge tube, and before lysis in CTAB extraction buffer, $1 \mathrm{ml}$ washing buffer [ $80 \%$ anhydrous ethanol, $2 \%$ $(\mathrm{w} / \mathrm{v}) \beta$-mercaptoethanol]was added, mixed well and centrifuged at $8,000 \mathrm{~g}$ for $10 \mathrm{~min}$ at room temperature. Discard the supernatant, and add $1 \mathrm{ml}$ washing buffer into the precipitate and centrifuge at $8000 \mathrm{~g}$ for $10 \mathrm{~min}$ again. The additional steps follow Method 3 as described.

\section{Method 6}

Transfer $0.2 \mathrm{~g}$ frozen sample powder to a $2 \mathrm{ml}$ centrifuge tube, and add $1 \mathrm{ml}$ washing buffer [ $80 \% 70 \%$ ac- etone, 2\%(w/v) $\beta$-mercaptoethanol ], mix well and centrifuge at $8,000 \mathrm{~g}$ for $10 \mathrm{~min}$ at room temperature. Discard the supernatant, and then add $1 \mathrm{ml}$ washing buffer into the precipitate and centrifuge at $8,000 \mathrm{~g}$ for $10 \mathrm{~min}$ again. After that, let the precipitate lysis in CTAB extraction buffer. The additional steps follow Method 3 as described.

\section{$R N A$ quantity and quality analysis}

The integrity of total RNA was examined by electrophoresis on $1 \%$ formaldehyde denaturing agarose gels; sample loading volume was $3 \mu$ l. The purity and yield of total RNA isolated was assessed by measuring optical density (OD value) at 230, 260 and $280 \mathrm{~nm}$ using a spectrophotometer (BIO-RAD, Germany).

\section{Results}

Peel and pulp of young and ripe fruit as materials were evaluated with six methods of total RNA extraction. The yield and purity of total RNA in loquat from different stages were different based on the method used (Fig. 1 and Tab. 1).

With method 1, the total RNA of the young fruits had $\mathrm{A}_{260} / \mathrm{A}_{230}$ ratios lower than 2.0, suggesting that RNA samples were little contaminated by polysaccharides, proteins, DNA, phenol or salts. With ripe fruit, total RNA was difficult to detected by gel electrophoresis (Fig. 1, A) indicating method 1 failed to isolate total RNA.

Method 2 isolated total RNA and yields, especially for the pulp of ripe fruits, was the highest $(21.22 \mu \mathrm{g} / \mathrm{g} \mathrm{FW})$ of the six methods. However, the $\mathrm{A}_{260} / \mathrm{A}_{230}$ ratio (0.87-1.45) was low and the electrophoresis bands were indistinct (Fig. 1, B).

Method 3 proved to be a practical method for RNA extraction. The RNA samples can be used for further study because their $\mathrm{A}_{260} / \mathrm{A}_{280}$ and $\mathrm{A}_{260} / \mathrm{A}_{230}$ ratios were 1.87-2.05 and 2.32-3.62. Furthermore, distinct bands of $28 \mathrm{~S}, 18 \mathrm{~S}$ ri-

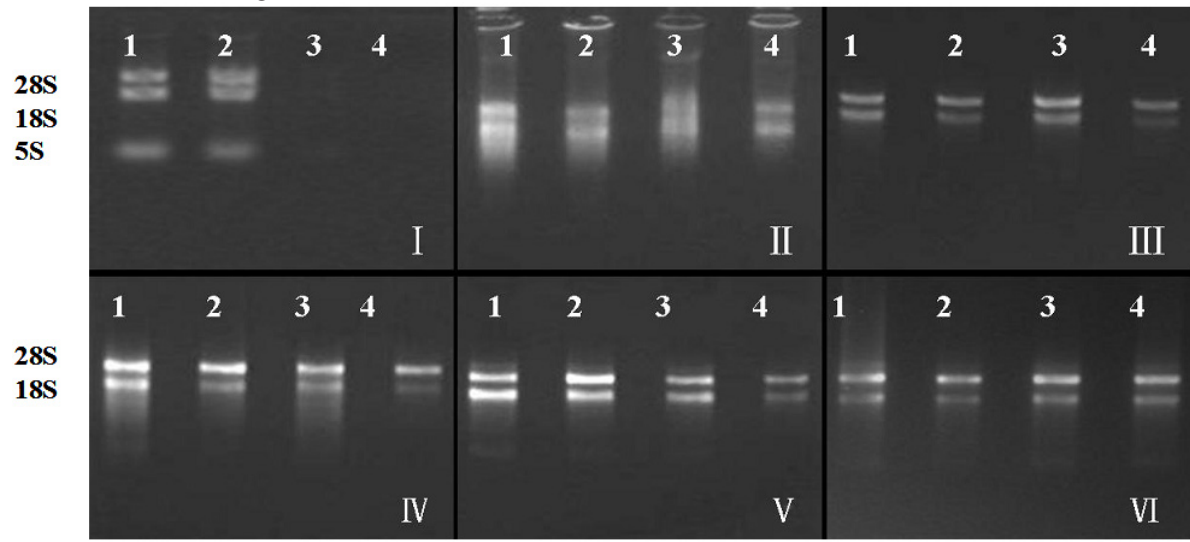

Fig. 1. Electrophoretogram of total RNA extracted from loquat fruit

I -method 1; II - method 2; III-method 3; iv - method 4; V-method 5; VI-method 6; Lane 1: peel of young fruit; Lane 2: pulp of young fruit; Lane 3: peel of ripe fruit; Lane 4: pulp of ripe fruit 
Tab. 1. Yield and absorbance ratio of total RNA extracted from loquat fruit with different methods

\begin{tabular}{|c|c|c|c|c|}
\hline Method & Material & $\begin{array}{l}\text { Yield of total RNA } \\
(\mu \mathrm{g} / \mathrm{g} F W)\end{array}$ & $\mathrm{OD}_{260} / \mathrm{OD}_{280}$ & $\mathrm{OD}_{260} / \mathrm{OD}_{230}$ \\
\hline \multirow{4}{*}{1} & 1 & 53.24 & 1.86 & 1.18 \\
\hline & 2 & 21.00 & 1.88 & 0.94 \\
\hline & 3 & 3.88 & 1.83 & 0.67 \\
\hline & 4 & 2.14 & 2.06 & 0.57 \\
\hline \multirow{4}{*}{2} & 1 & 39.76 & 1.88 & 1.45 \\
\hline & 2 & 15.20 & 1.87 & 1.37 \\
\hline & 3 & 33.20 & 1.75 & 0.65 \\
\hline & 4 & 21.22 & 1.78 & 0.87 \\
\hline \multirow{4}{*}{3} & 1 & 42.26 & 2.05 & 2.63 \\
\hline & 2 & 27.46 & 1.99 & 2.32 \\
\hline & 3 & 19.60 & 2.00 & 2.62 \\
\hline & 4 & 6.46 & 1.87 & 3.62 \\
\hline \multirow{4}{*}{4} & 1 & 31.28 & 1.97 & 2.45 \\
\hline & 2 & 22.60 & 1.95 & 2.86 \\
\hline & 3 & 14.63 & 2.08 & 2.29 \\
\hline & 4 & 5.47 & 1.89 & 3.14 \\
\hline \multirow{4}{*}{5} & 1 & 31.58 & 1.86 & 3.68 \\
\hline & 2 & 40.62 & 1.97 & 2.65 \\
\hline & 3 & 23.47 & 1.99 & 2.99 \\
\hline & 4 & 9.24 & 1.81 & 2.78 \\
\hline \multirow{4}{*}{6} & 1 & 56.78 & 2.06 & 2.51 \\
\hline & 2 & 15.66 & 1.91 & 3.61 \\
\hline & 3 & 40.86 & 2.08 & 2.58 \\
\hline & 4 & 5.98 & 1.87 & 2.31 \\
\hline
\end{tabular}

Note: 1 peel of young fruit; 2 pulp of young fruit; 3 peel of ripe fruit; 4 pulp of ripe fruit

bosomal RNA were observed in electrophoresis pictures (Fig. 1, C). However, the low yield $(6.46 \mu \mathrm{g} / \mathrm{g} \mathrm{FW})$ obtained from the pulp of ripe fruit is considered to be the only shortcoming.

In order to obtain high yield and high quality of total RNA, the sample powder was pre-processed with three different washing buffers before lysis in the CTAB extraction buffer. Methods 4, 5, and 6 were developed based on this concept. Compared with method 1 and method 2 , total RNA isolated by using method 4, 5, and 6, were superior with high purity for loquat fruit. Their $\mathrm{A}_{260} / \mathrm{A}_{280}$ ratios ranged from 1.81 to 2.08 and $\mathrm{A}_{260} / \mathrm{A}_{230}$ ratios ranged from 2.29 to 3.68. Distinct bands of $28 \mathrm{~S}$ and $18 \mathrm{~S}$ ribosomal RNA were also observed in electrophoresis picture (Fig. $1, \mathrm{D}, \mathrm{E}, \mathrm{F})$. These results indicated that high quality total RNA could be isolated from peel or purl by pretreatment although yields different.

\section{Discussion}

Although there are many methods for RNA isolation, there is no universal one for all plant species or organs. Even identical tissues at different development stages may require a special protocol of RNA isolation due to the variability of chemical compositions and content (Sharma et al., 2003; Wang et al., 2007). Loquat is a recalcitrant woody fruit tree; its peel and pulp during differentiation contain more abundant and intricate polysaccharides, proteins, and secondary metabolites such as polyphenols than those of herbaceous plants (Liu et al., 2005), causing great difficulty to isolate total RNA with high quality and high yield.

The traditional Trizol kit which is the most common RNA isolation method is easy to operate and saves time and labor. Method 1 is a modification based on this kit and proved to be effective for RNA isolation from papaya and tomato fruits (He et al., 2010; Lin et al., 2008); however, this improved method failed to isolate total RNA from loquat fruit. The RNAiso kit is used for polysaccharide-rich plant tissue (TaKaRa, Japan) rich in polysaccharides and polyphenols can isolate RNA from loquat fruit. However, the low $\mathrm{A}_{260} / \mathrm{A}_{230}$ ratio $(0.87-1.45)$ and indistinct bands in electrophoresis picture (Fig. 1, B) indicated that RNA isolated by this method may contain many chemical substances, such as DNA, phenols, polysaccharides and salt, which could lead to negative effects.

Song et al. (2011) reported that improved CTAB-LiCl extraction was a practicable protocol for loquat buds at different stages. Our study indicated that improved CTAB$\mathrm{LiCl}$ extraction is satisfactory for loquat fruit. The only disadvantage is the low yield $(6.46 \mu \mathrm{g} / \mathrm{g} \mathrm{FW})$ obtained from ripe fruit pulp. 
316

Previous studies suggested that high quality and high yield total RNA could be isolated from apricot ( $\mathrm{Li}$ et al., 2010), plum (Xu et al., 2010), litchi (Zhang et al, 2004), mango (Xiao et al., 2003; Zhang et al., 2009) and sisal (Zhang et al., 2010) when the sample powder was pre-processed by washing buffer before lysis in CTAB extraction buffer. Our study also confirmed that pretreatment with washing buffer, especially with $80 \%$ ethanol and $70 \%$ acetone, can effectively improve the quality of isolated RNA. We acknowledge that isolated RNA yields show slight differences based on method. For example, when using the $80 \%$ ethanol as the washing buffer, we obtained the highest yield of RNA ( $40.62 \mu \mathrm{g} / \mathrm{g} \mathrm{FW}$ ) from young fruit pulp using the $70 \%$ acetone, while highest yields were obtained from peels of both young $(57.68 \mu \mathrm{g} / \mathrm{g} \mathrm{FW})$ and ripe fruits $(40.86 \mu \mathrm{g} / \mathrm{g} \mathrm{FW})$. The experimental results demonstrated that total RNA isolated by method 5 and 6 were quite high in purity, proved to be suitable for fruit, and satisfactory for molecular downstream applications.

\section{Acknowledgement}

This work was supported by the National Natural Science Foundation of China (No. 30971836) and Key Laboratory of Innovation and Utilization for Germplasm Resources in Horticultural Crops in Southern China of Guangdong Higher Education Institutes, South China Agricultural University, and our sincere thanks go to Prof. Jules Janick for constructive comments on the manuscript preparation.

\section{References}

He JX, Chen L, Guo XL, Yu YJ, Yang L (2010). An improved method for extracting RNA from tomato fruit. Biotech. Bull 8:150-152.

Li XY, Cao X, Fang JG, Zhang Z (2010). Study on methods for RNA extraction from apricot leaf and fruit. Chinese Agri Sci Bull 26(2):152-156.
Lin Y, Chen XJ (2008). Comparison of methods for RNA extraction from papaya fruit. Sub Agric Res 4(3):229-232.

Liu YX, Yang XH, Lin SQ, Hu GB, Liu CM (2005). An improved procedure for nuclear DNA isolation from Eriobotrya plants and its application. J Fruit Sci 22(2):182-185.

Sharma, AD, Gill PK, Singh P (2003). RNA isolation from plant tissues rich in polysaccharides. Anal Biochem 314(2):319321.

Song HW, Liu YX, Hu GB, Qin YH, Lin SQ (2011). An improved method for total RNA isolation from recalcitrant loquat (Eriobotrya japonica Lindl.) buds. Pak J Bot 43(2):1-9.

Wang, SX, Hunter W, Plant A (2000). Isolation and purification of functional total RNA from woody branches and needles of Sitka and white spruce. Biotechniques 28(2):292-296.

Wang, W , Liang GL, Xie JH (2007). A study of the methods for total RNA extraction from different tissues of banana. Journal of Southwest China Normal University (Natural Science Edition) 32(1):62-68.

Xiao JN, Huang XL, Li Y, Huang X, Li XJ (2003). RNA extraction from cotyledon of mango with high levels of secondary substances and carbohydrates. China Biotech 23(11):8386.

Xu QH, Zhang Z, Tong .G, Gao ZH, Qu SC, Qiao YS (2010). Effect of sorbitol on total RNA isolation from plum fruit flesh. Jiangsu J Agr Sci 26(2):390-394.

Zhang YH, Xiang X, Fu JR, Huang SZ (2004). A method for extraction of total RNA from litchi embryo. Plant Physiol Commun 40(2):226-228.

Zhang Y, Tang ZP, Deng HY, Wang CJ (2009). Isolation of total RNA from mango pulp tissue rich in polysaccharides and polyphenols. J Hunan Agric Univ Natural Sci 35(6):637639.

Zhang YM, Zhou WZ, Li JF (2010). Comparative analysis of different RNA isolation methods for dissimilar tissues of $\mathrm{Si}$ sal. Mol Plant Breed 8(1):201-208. 